\title{
The response of broiler chicks to diets supplemented with whole or oligosaccharide- free lupin seed meals.
}

\author{
P. A. Iji ${ }^{\text {\# }}$, R. J. Hughes ${ }^{2}$, M. Choct ${ }^{3}$ and D. R. Tivey ${ }^{2}$ \\ ${ }^{1}$ School of Agric Sciences and Agribusiness, University of Natal, P Bag X01, Scottsville, 3209 \\ ${ }^{2}$ Dept of Animal Science, The University of Adelaide, Waite Campus, Glen Osmond 5064, Australia. ${ }^{3}$ Dept of Animal \\ Science, University of New England, Armidale 2359, Australia. \\ ${ }^{\#}$ Email:ijipa@ansi.unp.ac.za
}

\section{Introduction}

Lupin seed meal (LSM) is a potential replacement for costly oilseed cakes as a source of protein. However, poultry productivity on diets supplemented with LSM is lower than that on diets supplemented with oilseed cakes. This is often attributed to the presence of raffinose oligosaccharides in LSM. Research on other legume seed meals has yielded varying results with regards to the effects of raffinose oligosaccharides on diet quality and poultry productivity (Coon, 1990; Leske et al., 1993; Irish et al., 1995). A study was therefore, conducted to investigate the benefits of extracting oligosaccharides from Australian narrow-leafed lupin (Lupinus angustifolius) seed meals, prior to inclusion in diets. The mechanisms involved at the level of the intestinal mucosa were also assessed.

\section{Materials and Methods}

Ninety-six mixed-sex Inghams IM98 (Inghams Enterprises Aus. Pty Ltd) broiler chicks (initial weight $943 \pm$ $27 \mathrm{~g}$ ), 21 days of age were used for the study. The chicks were randomly assigned in groups of four to multi-bird metabolic cages and provided with one of four diets, based on sorghum $(543.0 \mathrm{~g} / \mathrm{kg})$ and casein $(91.0 \mathrm{~g} / \mathrm{kg})$. Each diet also contained $(\mathrm{g} / \mathrm{kg})$ : dicalcium phosphate (26.0), limestone (11.0), celite (diatomaceous earth) marker (26.0), vitamin premix (5.0), sodium chloride (3.6) and choline chloride (0.4). In addition, the diets were supplemented with de-hulled seed meals from two cultivars of L. angustifolius $(300 \mathrm{~g} / \mathrm{kg}$ ). Both cultivars, Gungurru and Danja were used as whole meals (diets Gung+ and Danja+ respectively) or as meals from which most of the oligosaccharides had been removed (diets Gung and Danja respectively) through solvent (ethanol) extraction. There were six replicates (cages) per diet. The experiment was designed primarily for classical AME evaluation, and consisted of three days of adaptation to the diets, followed by 4 days of total faecal collection and measurement of feed consumption and growth. Intestinal samples were collected at the end of the trial and used to assess mucosal morphometry and expression of digestive enzymes.

\section{Results and Discussion}

The extraction of oligosaccharides from seed meals of both varieties of lupins increased the gross energy (GE) but reduced the crude protein and AME contents of the diets (Table 1).

Table 1. Feed intake, weight gain, feed conversion ratio and apparent metabolizable energy of diets.

Results are presented as means \pm standard deviations.

\begin{tabular}{lcccc}
\hline & Gung & Gung+ & Danja & Danja+ \\
\hline Initial weight (g) & $949 \pm 26$ & $946 \pm 18$ & $940 \pm 43$ & $937 \pm 22$ \\
Weight gain (g) & $376 \pm 52^{\mathrm{b}}$ & $429 \pm 18^{\mathrm{a}}$ & $378 \pm 43^{\mathrm{b}}$ & $420 \pm 34^{\mathrm{a}}$ \\
Gross energy (MJ/kg DM) & 17.1 & 16.4 & 17.0 & 16.2 \\
AME (MJ/kg DM) & $13.0 \pm 0.3$ & $13.8 \pm 0.3$ & $12.6 \pm 0.5$ & $13.4 \pm 0.3$ \\
Crude protein (g/kg DM) & 234.9 & 250.5 & 222.0 & 239.1 \\
Feed intake (g/day) & $111 \pm 8^{\mathrm{b}}$ & $123 \pm 5^{\mathrm{a}}$ & $111 \pm 10^{\mathrm{b}}$ & $122 \pm 7^{\mathrm{a}}$ \\
Feed conversion ratio (FCR) & $2.15 \pm 0.25$ & $2.01 \pm 0.08$ & $2.13 \pm 0.19$ & $2.04 \pm 0.06$ \\
Faecal moisture (\%) & $74.0 \pm 3.0$ & $73.0 \pm 2.0$ & $74.0 \pm 3.0$ & $74.0 \pm 3.0$ \\
Ileal digesta viscosity & $15.2 \pm 10.2^{\mathrm{ab}}$ & $6.8 \pm 4.0^{\mathrm{c}}$ & $17.6 \pm 7.0^{\mathrm{a}}$ & $8.4 \pm 3.0^{\mathrm{bc}}$ \\
\hline
\end{tabular}


Short paper and poster abstracts: $38^{\text {th }}$ Congress of the South African Society of Animal Science

${ }^{\mathrm{a}, \mathrm{b}, \mathrm{c}}$ Mean values in the same row not sharing a common superscript are significantly different $(\mathrm{P}<0.05)$. ${ }^{1}$ The crude protein (CP) content of individual ingredients was determined and the values used to calculate diet CP; no statistical tests were conducted on GE and CP contents.

Feed intake by chicks on the diets containing the extracted meals was lower $(\mathrm{P}<0.05)$ than that observed for diets with the whole seed meals. Body weight gain was higher $(\mathrm{P}<0.05)$ on the unextracted lupin diets than on the diets supplemented with the extracted meals. Supplementation with the extracted lupin meals led to marginal increases in FCR, compared with diets supplemented with unextracted meals. There were no significant differences between the groups in faecal moisture content but ileal digesta viscosity was increased $(\mathrm{P}<0.05)$ in chicks maintained on the diets supplemented with the extracted seed meals.

Table 2 Expression of intestinal enzymes $\left(\mathrm{Ab} . / \mu \mathrm{m}^{2}\right)$ in chicks fed diets with whole or oligosaccharidefree lupins. Results are presented as means \pm standard deviations.

DIET

\begin{tabular}{lcccc}
\hline & Gung & Gung+ & Danja & Danja+ \\
\hline A. Duodenum & & & & \\
AG & $0.44 \pm 0.066$ & $0.42 \pm 0.094$ & $0.43 \pm 0.032$ & $0.45 \pm 0.048$ \\
APN & $0.34 \pm 0.050$ & $0.43 \pm 0.133$ & $0.48 \pm 0.107$ & $0.43 \pm 0.138$ \\
AP & $0.33 \pm 0.018^{\mathrm{a}}$ & $0.20 \pm 0.019^{\mathrm{ab}}$ & $0.14 \pm 0.027^{\mathrm{b}}$ & $0.24 \pm 0.031^{\mathrm{ab}}$ \\
B. Jejunum & & & & \\
AG & $0.49 \pm 0.034$ & $0.54 \pm 0.093$ & $0.52 \pm 0.099$ & $0.57 \pm 0.066$ \\
APN & $0.41 \pm 0.093$ & $0.45 \pm 0.189$ & $0.32 \pm 0.061$ & $0.42 \pm 0.143$ \\
AP & $0.18 \pm 0.057$ & $0.18 \pm 0.067$ & $0.17 \pm 0.072$ & $0.19 \pm 0.086$ \\
C. Ileum & & & & \\
AG & $0.50 \pm 0.116$ & $0.42 \pm 0.021$ & $0.48 \pm 0.118$ & $0.49 \pm 0.091$ \\
APN & $0.38 \pm 0.083$ & $0.58 \pm 0.120$ & $0.47 \pm 0.094$ & $0.45 \pm 0.133$ \\
AP & $0.23 \pm 0.089$ & $0.27 \pm 0.047$ & $0.17 \pm 0.023$ & $0.16 \pm 0.043$ \\
\hline
\end{tabular}

$\mathrm{a}, \mathrm{b}$ - Mean values in the same row not sharing a common superscript are significantly different $(\mathrm{P}<0.001)$. Four chicks were assessed per diet and five well presented villi were measured per sample.

No significant differences were observed in the morphometry of the intestinal mucosa of chicks fed the different diets. No dietary effects were observed on the expression of $\alpha$-glucosidase (AG) or aminopeptidase $\mathrm{N}$ (APN) in three regions of the small intestine (Table 2). The activity of alkaline phosphatase (AP) was lower (P < 0.001) in the duodenum of chicks raised on Danja diet than in chicks on the other diets but there were no precise effects of oligosaccharides. On the Danja-supplemented diet, AP activity was reduced in chicks fed the diets supplemented with the extracted meal while there was an increase in the case of cultivar Gungurru. There were also no significant differences between diets in activity per cell for any of the digestive enzymes in the jejunum or ileum.

\section{Conclusions}

The extraction of raffinose series oligosaccharides from lupin seed meals improved the gross energy content of the diets but this was associated with a reduction in metabolizable energy and crude protein values and tended to reduce broiler chicken growth. Intestinal structure and enzyme function were not adversely affected by the presence of the oligosaccharides in the diets over the short term. It would be desirable to assess these effects over a longer duration of feeding.

\section{References}

Coon, C.N. et al., 1990. Poultry Sci. 69, 787.

Irish, G.G. et al., 1995. Poultry Sci. 74, 1484.

Leske, K.L. et al., 1993. Poultry Sci. 72, 664. 